\title{
Hierarchical $\mathrm{Sb}_{2} \mathrm{~S}_{3} / \mathrm{SnS}_{2} / \mathrm{C}$ heterostructure with improved performance for sodium-ion batteries
}

\author{
Rui Jia ${ }^{1,2}$, La Li ${ }^{2}$, Guozhen Shen ${ }^{2 *}$ and Di Chen ${ }^{1 *}$
}

\begin{abstract}
Metal sulfides are promising anode materials for sodium-ion batteries (SIBs) because of their high theoretical capacities. However, they are usually limited by their poor cycling performance and rate properties due to their large volume expansion and sluggish reaction kinetics. Herein, $\mathrm{Sb}_{2} \mathrm{~S}_{3} / \mathrm{SnS}_{2} / \mathrm{C}$ heterostructures were fabricated by directly growing $\mathrm{SnS}_{2}$ nanoplates on $\mathrm{Sb}_{2} \mathrm{~S}_{3}$ nanorods and then coating their surface with a carbon layer. Sodium-ion diffusion in several electrodes and different electrolytes was further evaluated to investigate the electrochemical performance of the heterostructures. Results revealed that the heterostructures greatly enhanced material stability and promoted ion and electron transport. Consequently, the $\mathrm{Sb}_{2} \mathrm{~S}_{3} / \mathrm{SnS}_{2} / \mathrm{C}$ composites displayed a high reversible capacity of $642 \mathrm{~mA} \mathrm{~h} \mathrm{~g}^{-1}$ at a current density of $1 \mathrm{~A} \mathrm{~g}^{-1}$ after 600 cycles and a good rate performance of $367.3 \mathrm{~mA} \mathrm{~h} \mathrm{~g}^{-1}$ at $4 \mathrm{~A} \mathrm{~g}^{-1}$ in a $\mathrm{NaPF}_{6}$-diglyme electrolyte. Therefore, $\mathrm{Sb}_{2} \mathrm{~S}_{3} / \mathrm{SnS}_{2} / \mathrm{C}$ heterostructures are promising anode materials for SIBs.
\end{abstract}

Keywords: $\mathrm{Sb}_{2} \mathrm{~S}_{3} / \mathrm{SnS}_{2} / \mathrm{C}$ heterostructures, anode, electrolyte, sodium-ion battery

\section{INTRODUCTION}

Energy storage plays an increasingly important role in our daily life. At present, the main power units of portable electronics, electric vehicles, and home appliances are lithium-ion batteries, whose development is restricted by their high price and limited resources [1-6]. As a substitute, sodium-ion batteries (SIBs) can be used for energy storage and have attracted wide attention. However, SIBs still face the problem of unsatisfactory electrochemical performance because of the large radius of sodium ion [7-9]. Thus, more suitable electrode materials and systems should be developed for high-performance energy storage devices.

Previous studies extensively investigated various electrode materials, including carbon materials, metal oxides, alloys, and metal sulfides [10-15]. Among them, metal sulfides have been profoundly explored because of their high theoretical capacity, low cost, and variety. For instance, $\mathrm{Sb}_{2} \mathrm{~S}_{3}$ and $\mathrm{SnS}_{2}$ have high theoretical capacities of 946 and $1136 \mathrm{~mA} \mathrm{~h} \mathrm{~g}^{-1}$, respectively, and they participate in conversion and alloying reactions $[16,17]$. However, the sluggish reaction kinetics of $\mathrm{Na}^{+}$in bulk $\mathrm{SnS}_{2}$ and $\mathrm{Sb}_{2} \mathrm{~S}_{3}$ limit the rate of sodiation/desodiation, resulting in a low power density. Additionally, the large volume expansion during sodium-ion insertion/extraction can cause serious damage to electrodes and yield a poor electrochemical cycling performance. As such, efforts have been devoted to improving the electrochemical properties of devices by preparing special micro/nanostructures and introducing carbon materials [18-23]. Furthermore, constructing metallic sulfide-based heterostructures can effectively relieve internal pressure and maintain structural integrity during ion intercalation/de-intercalation. Introducing carbon layers helps enhance the electrical conductivity and buffer volume expansion of electrode materials. For example, $\mathrm{Xu}$ and co-workers [22] synthesized a $\mathrm{Sb}_{2} \mathrm{~S}_{3} / \mathrm{MoS}_{2}$ heterostructure as an anode material for SIBs. They obtained an initial reversible capacity of $701 \mathrm{~mA} \mathrm{~h} \mathrm{~g}^{-1}$ at a current density of

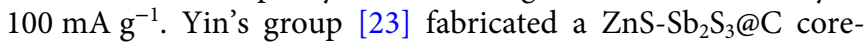
double shell polyhedron structure from a metal-organic framework. This composite serves as anode materials in SIBs and demonstrates a reversible capacity of $630 \mathrm{~mA} \mathrm{~h} \mathrm{~g}^{-1}$ at $100 \mathrm{~mA} \mathrm{~g}^{-1}$ after 120 cycles. Consequently, the heterogeneous interface between the two different metal sulfides may generate an internal electric field and provide special channels; thus, the electrochemical performance and structural stability of composites improve. Moreover, Ding's group [19] fabricated a threedimensional $\mathrm{SnS}_{2}$ flower/carbon nanotube network that yields a reversible capacity of $460 \mathrm{~mA} \mathrm{~h} \mathrm{~g}^{-1}$ at $20 \mathrm{~mA} \mathrm{~g}^{-1}$. Ji's group [18] reported that one-dimensional $\mathrm{Sb}_{2} \mathrm{~S}_{3} @ \mathrm{C}$ rod-based SIBs have a high capacity of $699.1 \mathrm{~mA} \mathrm{~h} \mathrm{~g}^{-1}$ after 100 cycles at a current density of $100 \mathrm{~mA} \mathrm{~g}^{-1}$, because of the introduced carbon layer relieving the change in volume.

Electrolytes also play a crucial role in batteries with a stable voltage window and superior electrochemical performance. Many researchers found that the capacity and cycling stability of electrodes in ether-based electrolytes can be improved compared with those in carbonate-based electrolytes [24-27]. Using etherbased electrolytes can induce a thinner and more stable solid electrolyte interphase (SEI) film on the electrode surfaces than using carbonate-based electrolytes because of the lower reduction voltage of ether-based solvents [24]. Thus, choosing the appropriate electrolyte with a stable working voltage is essential for high-performance battery systems.

In this work, hierarchical metallic sulfides of $\mathrm{Sb}_{2} \mathrm{~S}_{3} / \mathrm{SnS}_{2} / \mathrm{C}$ composites were prepared and used as anodes for SIBs. Different electrolytes were utilized to investigate their effects on the $\mathrm{Na}$ storage performance of electrodes based on $\mathrm{Sb}_{2} \mathrm{~S}_{3} / \mathrm{SnS}_{2} / \mathrm{C}$ composites. The optimized system of $\mathrm{Sb}_{2} \mathrm{~S}_{3} / \mathrm{SnS}_{2} / \mathrm{C}$ electrode in a $\mathrm{NaPF}_{6}$-diglyme electrolyte was used for the following in-depth

\footnotetext{
${ }^{1}$ School of Mathematics and Physics, University of Science and Technology Beijing, Beijing 100083, China

${ }^{2}$ State Key Laboratory for Superlattices and Microstructures, Institute of Semiconductors, Chinese Academy of Sciences, Beijing 100083, China

* Corresponding authors (emails: chendi@ustb.edu.cn (Chen D); gzshen@semi.ac.cn (Shen G))
} 
measurements. Our results revealed that the system delivered a high reversible capacity of $642 \mathrm{~mA} \mathrm{~h} \mathrm{~g}^{-1}$ after 600 cycles at $1 \mathrm{~A} \mathrm{~g}^{-1}$ and a good rate performance of $367.3 \mathrm{~mA} \mathrm{~h} \mathrm{~g}^{-1}$ at $4 \mathrm{~A} \mathrm{~g}^{-1}$. With superior electrochemical performance, the system of the $\mathrm{Sb}_{2} \mathrm{~S}_{3} / \mathrm{SnS}_{2} / \mathrm{C}$ heterojunction in the $\mathrm{NaPF}_{6}$-diglyme electrolyte can be considered a promising candidate for practical application in SIBs.

\section{EXPERIMENTAL SECTION}

\section{Material synthesis}

Preparation of $\mathrm{Sb}_{2} \mathrm{~S}_{3}$ nanorods

In this work, synthesis was performed in accordance with a previously described method with some modifications [28]. First, $0.596 \mathrm{~g}$ of $\mathrm{Sb}\left(\mathrm{CH}_{3} \mathrm{COO}\right)_{3}$ was dissolved in a mixed solution containing $16 \mathrm{~mL}$ of ethanol and $6 \mathrm{~mL}$ of glycerol and continuously stirred for $30 \mathrm{~min}$. Then, $0.3 \mathrm{~g}$ of thioacetamide (TAA) was added to the above solution under vigorous stirring for another $30 \mathrm{~min}$. The obtained solution was transferred into a 40-mL Teflon autoclave, which was heated to $180^{\circ} \mathrm{C}$ for $10 \mathrm{~h}$. After being cooled to room temperature, a black product was collected, washed with deionized (DI) water and ethanol several times, and dried in a vacuum oven at $80^{\circ} \mathrm{C}$ for $12 \mathrm{~h}$.

\section{Preparation of $\mathrm{Sb}_{2} \mathrm{~S}_{3} / \mathrm{SnS}_{2}$ dendritic heterostructures}

$\mathrm{SnS}_{2}$ was prepared in accordance with a previously described procedure [29]. In brief, $0.03 \mathrm{~g}$ of the as-prepared $\mathrm{Sb}_{2} \mathrm{~S}_{3}$ precursor and $0.5 \mathrm{~g}$ of cetyltrimethylammonium bromide (CTAB) were dispersed in $30 \mathrm{~mL}$ of isopropanol under ultrasonic treatment for $1 \mathrm{~h}$. In the following step, $0.2 \mathrm{~g}$ of $\mathrm{SnCl}_{4} \cdot 5 \mathrm{H}_{2} \mathrm{O}$ was added to the solution and stirred for $30 \mathrm{~min}$. Then, $0.25 \mathrm{~g}$ of TAA was placed in the well-dispersed solution. After being stirred evenly, the mixed solution was poured into a $40-\mathrm{mL}$ Teflon autoclave and reacted at $180^{\circ} \mathrm{C}$ for $6 \mathrm{~h}$. After the reaction was complete, the product was collected and rinsed with DI water and ethanol thrice. The sample was dried in a vacuum oven at $80^{\circ} \mathrm{C}$ for $12 \mathrm{~h}$.

\section{Fabrication of the $\mathrm{Sb}_{2} \mathrm{~S}_{3} / \mathrm{SnS}_{2} / \mathrm{C}$ composites}

Carbon coating was conducted in a manner similar to a previous report [30]. First, $0.03 \mathrm{~g}$ of polyvinylidene fluoride (PVDF) was dissolved in $20 \mathrm{~mL}$ of $\mathrm{N}$-methyl-2-pyrrrolidinone (NMP) to form a homogeneous solution. Then, $0.1 \mathrm{~g}$ of the $\mathrm{Sb}_{2} \mathrm{~S}_{3} / \mathrm{SnS}_{2}$ dendritic heterostructure was added to the solution and stirred for $4 \mathrm{~h}$. Subsequently, $20 \mathrm{~mL}$ of DI water was injected into the obtained solution with continuous stirring for $1 \mathrm{~h}$. The sample was centrifuged, dried, and calcined at $400^{\circ} \mathrm{C}$ for $2 \mathrm{~h}$ to obtain the $\mathrm{Sb}_{2} \mathrm{~S}_{3} / \mathrm{SnS}_{2} / \mathrm{C}$ composites. For comparison, $\mathrm{Sb}_{2} \mathrm{~S}_{3} / \mathrm{C}$ and $\mathrm{SnS}_{2} /$ $\mathrm{C}$ compounds were also fabricated using the same procedure.

\section{Characterizations}

Crystal texture was examined through X-ray diffraction (XRD) measurement by using a Bruker D8 Advance X-ray diffractometer with radiation from a $\mathrm{Cu}$ target $(\mathrm{Ka}, \lambda=$ $0.15406 \mathrm{~nm}$ ). The morphological characteristics of the samples were explored under a scanning electron microscope (SEM; Zeiss Supra 55) and a transmission electron microscope (TEM; JEOLJEM-2100HT). The chemical constituents of the products were probed with an X-ray photoelectron spectroscopy (XPS) system (Escalab 250-Xi). Thermogravimetric analysis (TGA;
NETZSCH STA 449 F3/F5) was performed under the following conditions: temperature range of $25-800^{\circ} \mathrm{C}$ and a heating rate of $10^{\circ} \mathrm{C} \mathrm{min}^{-1}$ in air.

\section{Electrochemical measurements}

The $\mathrm{Sb}_{2} \mathrm{~S}_{3} / \mathrm{C}, \mathrm{SnS}_{2} / \mathrm{C}$, and $\mathrm{Sb}_{2} \mathrm{~S}_{3} / \mathrm{SnS}_{2} / \mathrm{C}$ composite electrodes were first prepared by mixing the samples with carbon black and PVDF binder at a weight ratio of 7:2:1 in NMP solvent to fabricate SIBs. Next, the slurries were coated on copper foils and then dried in a vacuum oven at $80^{\circ} \mathrm{C}$ for $12 \mathrm{~h}$. The mass loading of the materials on the substrate was about $1 \mathrm{mg} \mathrm{cm}^{-2}$. A glass fiber GF/D membrane was used as a separator. Several drops of nanodiamond dispersion with a mass content of $5 \%$ were added to modify the GF/D membrane and further dried in a vacuum oven at $60^{\circ} \mathrm{C}$ for $12 \mathrm{~h}$ to improve the electrochemical performance of SIBs. The electrochemical properties of the $\mathrm{Sb}_{2} \mathrm{~S}_{3} / \mathrm{C}$, $\mathrm{SnS}_{2} / \mathrm{C}$, and $\mathrm{Sb}_{2} \mathrm{~S}_{3} / \mathrm{SnS}_{2} / \mathrm{C}$ electrodes were measured in CR2032 half cells with $\mathrm{Na}$ chips in the potential range of $0.01-3.0 \mathrm{~V}$. Then, $1 \mathrm{~mol} \mathrm{~L}^{-1} \mathrm{NaPF}_{6}$ in diglyme solvent and $1 \mathrm{~mol} \mathrm{~L}^{-1} \mathrm{NaPF}_{6}$ in ethylene carbonate (EC):dimethyl carbonate (DMC; $1: 1$ in volume) with $5 \%$ fluoroethylene carbonate (FEC) were used as electrolytes. A multichannel battery testing system (LandCT2001A) was applied to measure galvanostatic charge-discharge (GCD) curves, and a CHI760 electrochemical workstation was employed to test the cyclic voltammetry $(\mathrm{CV})$ curves of the batteries. The electrochemical impedance spectroscopy (EIS) plot in the frequency range of $0.01-10^{6} \mathrm{~Hz}$ was recorded, and the galvanostatic intermittent titration technique (GITT) was used on an AutoLab (PGSTAT302N) electrochemical analyzer. In GITT, a cell was discharged under a current density of $0.05 \mathrm{~A} \mathrm{~g}^{-1}$ for $5 \mathrm{~min}$ and allowed to rest in the voltage range of $0.01-3.0 \mathrm{~V}$ for $20 \mathrm{~min}$. A full cell was fabricated using NASICON-type $\mathrm{Na}_{3} \mathrm{~V}\left(\mathrm{PO}_{3}\right)_{3} \mathrm{~N}$ coated on $\mathrm{Al}$ foil as a cathode. The mass ratio of the anode and the cathode was around 1:8. Furthermore, $1 \mathrm{~mol} \mathrm{~L}^{-1} \mathrm{NaPF}_{6}$ in diglyme solvent and the same separator were used in the full cell. Before the full cell was assembled, the anode was activated in a half cell for three cycles at $0.1 \mathrm{~A} \mathrm{~g} \mathrm{~g}^{-1}$. The charge-discharge curves and cycling stability of the full cell were examined at the potential of $1-4 \mathrm{~V}$.

\section{RESULTS AND DISCUSSION}

The morphological characteristics and microstructures of $\mathrm{Sb}_{2} \mathrm{~S}_{3}$, $\mathrm{SnS}_{2}$, and $\mathrm{Sb}_{2} \mathrm{~S}_{3} / \mathrm{SnS}_{2}$ heterojunction were observed through SEM and TEM, respectively. Fig. 1a shows the SEM image of the hydrothermally produced $\mathrm{Sb}_{2} \mathrm{~S}_{3}$ nanorods with a diameter of around $100 \mathrm{~nm}$. Numerous $\mathrm{SnS}_{2}$ nanoplates were assembled to form flower-like structures with a diameter of 3-5 $\mu \mathrm{m}$ (Fig. S1a). Interestingly, the $\mathrm{SnS}_{2}$ nanoplates could be grown on the $\mathrm{Sb}_{2} \mathrm{~S}_{3}$ nanorod in situ by embellishing the $\mathrm{Sb}_{2} \mathrm{~S}_{3}$ precursor with CTAB. Clearly, as an ionic surfactant, $\mathrm{CTAB}$ can effectively reduce the surface tension and needs less energy to form new phases. It can also act as a carrier of growth units and influence the growth orientation of materials through its electrostatic and stereochemical effects [31]. In Fig. 1b, dendritic $\mathrm{Sb}_{2} \mathrm{~S}_{3} / \mathrm{SnS}_{2}$ heterostructures with a diameter of $\sim 1 \mu \mathrm{m}$ were obtained. After these heterostructures were further coated with the carbon layer, their morphological characteristics slightly changed (Fig. S1b). Fig. 1c illustrates the magnified SEM image of the $\mathrm{Sb}_{2} \mathrm{~S}_{3} / \mathrm{SnS}_{2} / \mathrm{C}$ materials and the nanosheets attached to the nanorod. By comparison, the mixtures of dispersed nanorods and nanoplate-based flower-like structures, not the dendritic heterostructures, were 

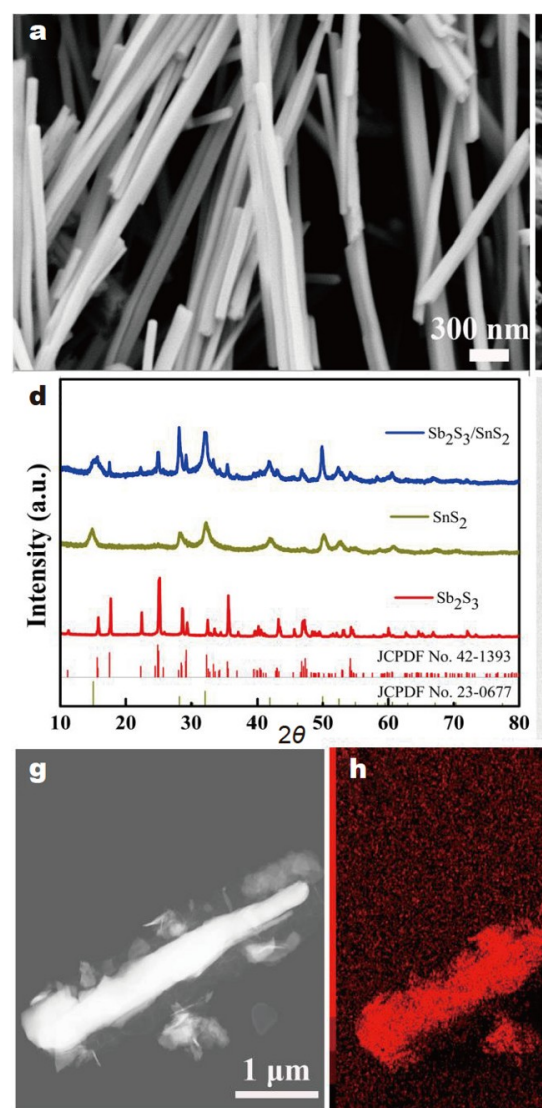
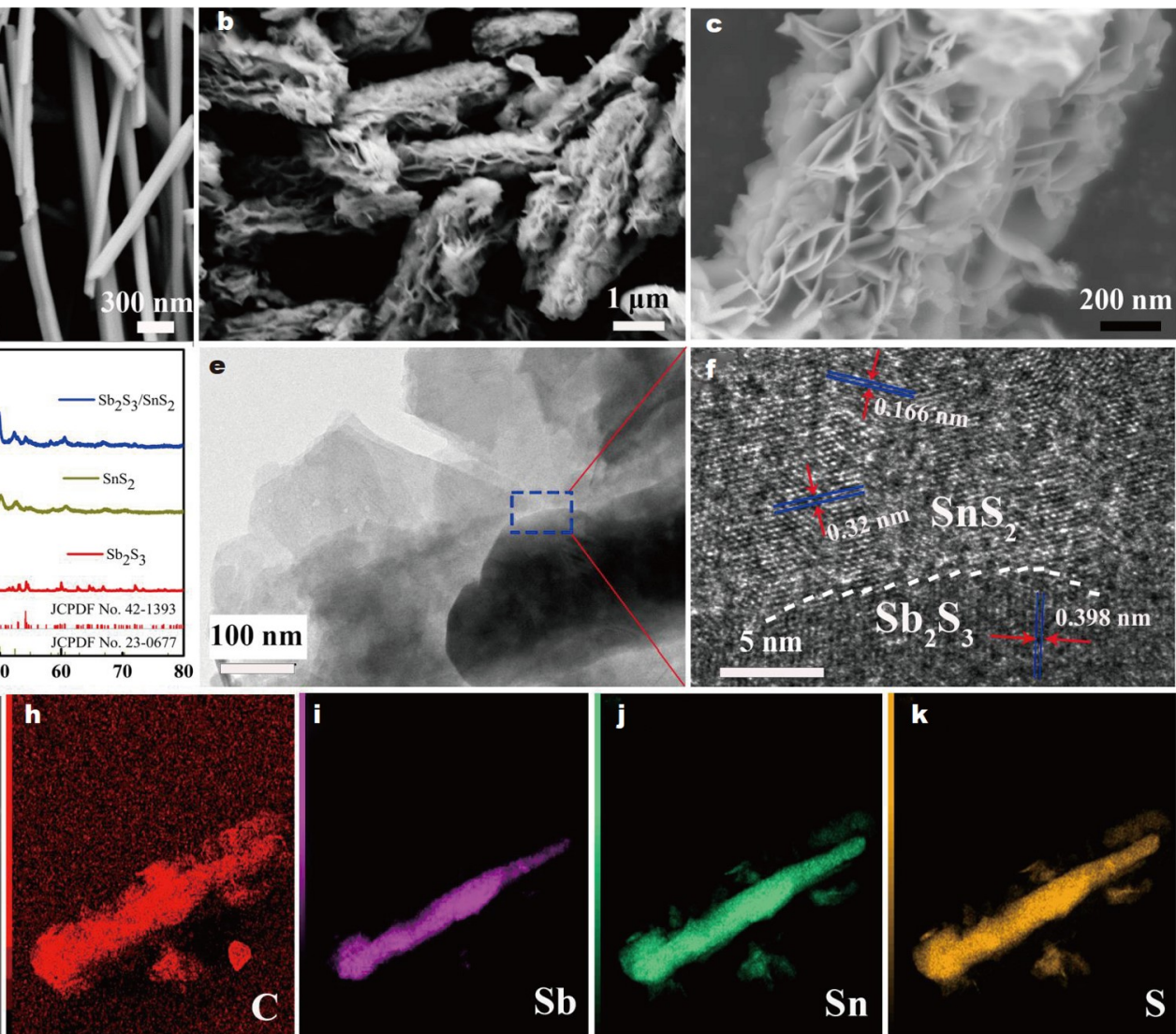

Figure 1 SEM images of (a) $\mathrm{Sb}_{2} \mathrm{~S}_{3}$, (b) $\mathrm{Sb}_{2} \mathrm{~S}_{3} / \mathrm{SnS}_{2}$, and (c) $\mathrm{Sb}_{2} \mathrm{~S}_{3} / \mathrm{SnS}_{2} / \mathrm{C}$. (d) XRD patterns of $\mathrm{Sb}_{2} \mathrm{~S}_{3}, \mathrm{SnS}_{2}$, and $\mathrm{Sb}_{2} \mathrm{~S}_{3} / \mathrm{SnS}_{2}$. (e, f) TEM and HRTEM images of $\mathrm{Sb}_{2} \mathrm{~S}_{3} / \mathrm{SnS}_{2} / \mathrm{C}$. (g-k) High-angle annular dark field (HAADF)-HRTEM image of $\mathrm{Sb}_{2} \mathrm{~S}_{3} / \mathrm{SnS}_{2} / \mathrm{C}$ and the corresponding energy dispersive X-ray spectroscopy (EDS) mappings of $\mathrm{C}, \mathrm{Sb}, \mathrm{Sn}$, and $\mathrm{S}$

prepared in the absence of CTAB (Fig. S2).

Fig. 1d presents the XRD patterns of the fabricated $\mathrm{Sb}_{2} \mathrm{~S}_{3}, \mathrm{SnS}_{2}$, and $\mathrm{Sb}_{2} \mathrm{~S}_{3} / \mathrm{SnS}_{2}$ materials. All of the diffractions of $\mathrm{Sb}_{2} \mathrm{~S}_{3}$ and $\mathrm{SnS}_{2}$ samples were consistent with the standard cards of JCPDS 421393 and JCPDS 23-0677, respectively [18,20]. Simultaneously, the XRD results of $\mathrm{Sb}_{2} \mathrm{~S}_{3} / \mathrm{SnS}_{2}$ and $\mathrm{Sb}_{2} \mathrm{~S}_{3} / \mathrm{SnS}_{2} / \mathrm{C}$ (Fig. S3) had similar diffraction peaks to those of pure $\mathrm{Sb}_{2} \mathrm{~S}_{3}$ and exhibited other strong peaks belonging to $\mathrm{SnS}_{2}$; therefore, $\mathrm{Sb}_{2} \mathrm{~S}_{3}$ and $\mathrm{SnS}_{2}$ were present in the heterostructure samples [16]. Fig. 1e depicts the TEM image of the $\mathrm{Sb}_{2} \mathrm{~S}_{3} / \mathrm{SnS}_{2} / \mathrm{C}$ heterostructures. The black bar denotes $\mathrm{Sb}_{2} \mathrm{~S}_{3}$, and the translucent plates correspond to $\mathrm{SnS}_{2}$. The selected area electron diffraction (SAED) and high-resolution TEM (HRTEM) images in Fig. S4a reveal that the $\mathrm{Sb}_{2} \mathrm{~S}_{3}$ nanorods were monocrystalline materials with clear lattice fingers of 0.566 and $0.398 \mathrm{~nm}$ corresponding to the (020) and (220) crystal faces. The SAED in the inset of Fig. S4b also illustrates the polycrystalline structure of the $\mathrm{SnS}_{2}$ nanoplate. The HRTEM image in Fig. S4b presents the interplanar distances of 0.320 , 0.210 , and $0.295 \mathrm{~nm}$, which could be indexed to (100), (102), and (002) lattice planes of $\mathrm{SnS}_{2}$. Fig. If shows the magnified blue marked area in Fig. 1e, where the crystal faces of (100) and (103) of $\mathrm{SnS}_{2}$ and the (220) of $\mathrm{Sb}_{2} \mathrm{~S}_{3}$ existed. This finding demonstrates that the $\mathrm{Sb}_{2} \mathrm{~S}_{3} / \mathrm{SnS}_{2}$ heterostructure is formed in the interface. Furthermore, the element distributions of the $\mathrm{Sb}_{2} \mathrm{~S}_{3} / \mathrm{SnS}_{2} / \mathrm{C}$ heterostructure were measured (Fig. 1g-k), and the results showed that $\mathrm{C}, \mathrm{Sb}, \mathrm{Sn}$, and $\mathrm{S}$ were distributed homogeneously in the sample.

The surface chemical compositions of $\mathrm{Sb}_{2} \mathrm{~S}_{3} / \mathrm{SnS}_{2} / \mathrm{C}$ were examined through XPS. Fig. 2a presents the overall XPS spectrum of the fabricated $\mathrm{Sb}_{2} \mathrm{~S}_{3} / \mathrm{SnS}_{2} / \mathrm{C}$ with the signals of $\mathrm{C}, \mathrm{Sb}, \mathrm{Sn}$, and $\mathrm{S}$, signifying the formation of the $\mathrm{Sb}_{2} \mathrm{~S}_{3} / \mathrm{SnS}_{2} / \mathrm{C}$ composite. High-resolution XPS spectra were obtained to further test the valence states of the elements. The $\mathrm{C}$ 1s spectrum in Fig. $2 \mathrm{~b}$ was fitted into three peaks at 284.6, 285.1, and $289.1 \mathrm{eV}$, which belong to $\mathrm{C}-\mathrm{C}, \mathrm{C}-\mathrm{S}$, and $\mathrm{C}=\mathrm{O}$, respectively [32]. Fig. 2c shows the Sn 3d spectrum with peaks at around 487.0 and $495.4 \mathrm{eV}$ corresponding to $S n 3 d_{5 / 2}$ and $S n 3 d_{3 / 2}$, respectively. The peaks of the $\mathrm{Sb} 3 \mathrm{~d}$ spectrum in Fig. 2d centered at 529.9 and $539.3 \mathrm{eV}$ are correlated with $\mathrm{Sb} 3 \mathrm{~d}_{5 / 2}$ and $\mathrm{Sb} 3 \mathrm{~d}_{3 / 2}$, respectively [33]. The binding energy at $532.4 \mathrm{eV}$ belongs to the $\mathrm{O} 1 \mathrm{~s}$ peak, representing surface hydroxyl groups [28]. As shown in Fig. 2e, the S 2p spectrum exhibits the peaks at 161.9 and $163.1 \mathrm{eV}$, which respond to $\mathrm{S}^{2-}$ in $\mathrm{S}-\mathrm{Sb} / \mathrm{S}-\mathrm{Sn}$, respectively. Besides, the peak at $164.9 \mathrm{eV}$ likely corresponds to the covalent bond with carbon [23]. According to the peak areas, the calculated atomic ratios of $\mathrm{Sb}$ and Sn were 23 and 77 at\%, respectively. The TGA result in Fig. $2 \mathrm{f}$ indicates that the contents of $\mathrm{C}, \mathrm{Sb}_{2} \mathrm{~S}_{3}$, and $\mathrm{SnS}_{2}$ were $9.9 \%, 19.6 \%$, and $70.5 \%$, respectively.

CR2032 coin cells were assembled by using the $\mathrm{Sb}_{2} \mathrm{~S}_{3} / \mathrm{SnS}_{2} / \mathrm{C}$ heterostructure, $\mathrm{Sb}_{2} \mathrm{~S}_{3} / \mathrm{C}, \mathrm{SnS}_{2} / \mathrm{C}$, and the samples prepared without $\mathrm{CTAB}$ as working electrodes and Na chip as a reference electrode to investigate the sodium-ion storage performance of the as-prepared samples. The SIBs with $\mathrm{NaPF}_{6}$-diglyme and $\mathrm{NaPF}_{6}$-EC/DMC electrolytes were used to compare the electrochemical performance. The $\mathrm{CV}$ curves of the electrodes in $1 \mathrm{~mol} \mathrm{~L}^{-1} \mathrm{NaPF}_{6}$-diglyme electrolyte (Fig. 3a and Fig. S5) were 

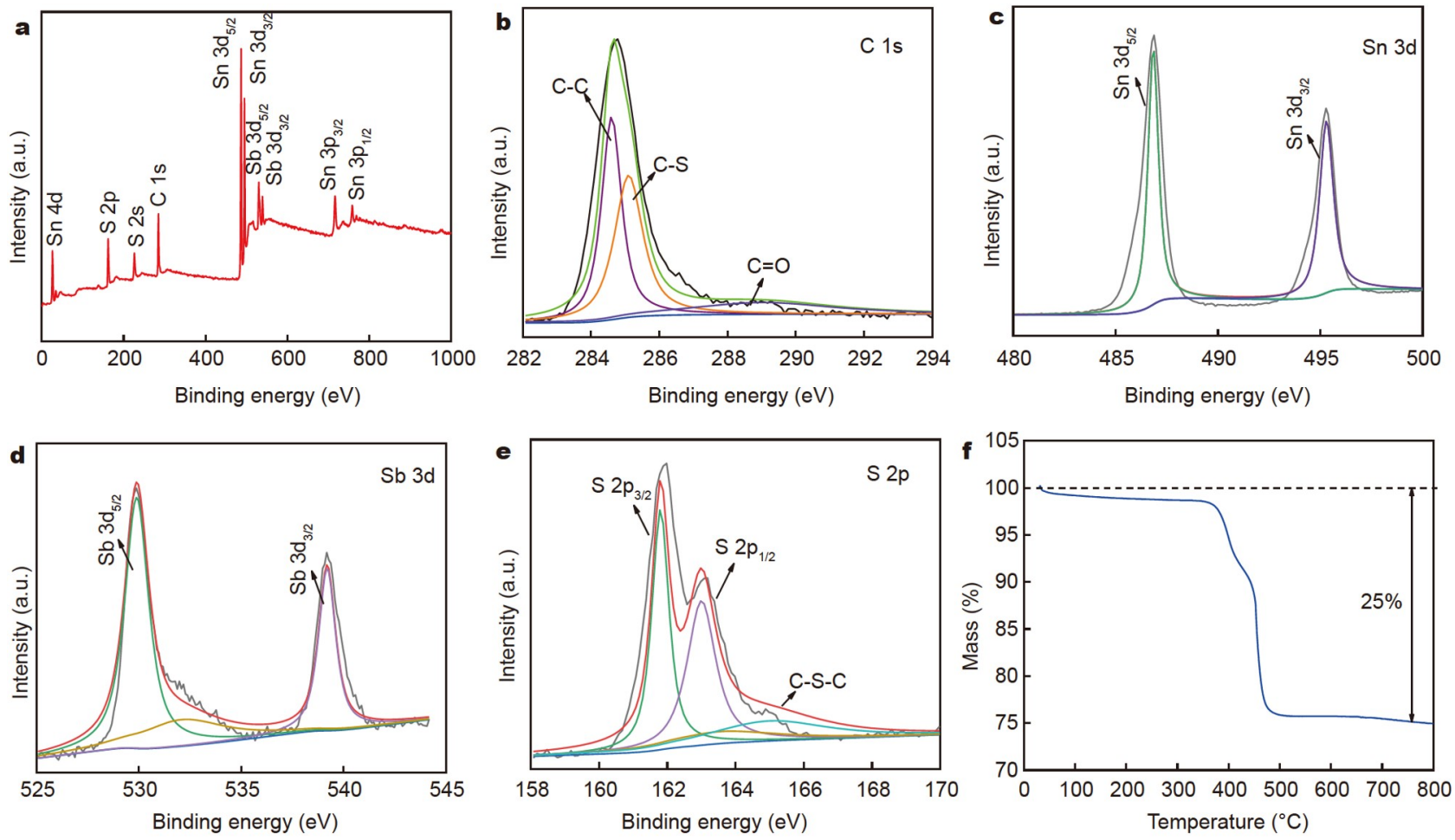

Figure 2 (a) XPS spectrum of $\mathrm{Sb}_{2} \mathrm{~S}_{3} / \mathrm{SnS}_{2} / \mathrm{C}$. (b-e) High-resolution XPS spectra of C 1s, Sn 3d, Sb 3d, and S 2p. (f) TGA curve of $\mathrm{Sb}_{2} \mathrm{~S}_{3} / \mathrm{SnS}_{2} / \mathrm{C}$.

tested in the potential range of $0.01-3.0 \mathrm{~V}$ at a scan rate of $1 \mathrm{mV} \mathrm{s}^{-1}$. The capacitance of $\mathrm{Sb}_{2} \mathrm{~S}_{3} / \mathrm{SnS}_{2} / \mathrm{C} \quad\left(1453 \mathrm{~F} \mathrm{~g}^{-1}\right.$, $1090 \mathrm{~mA} \mathrm{~h} \mathrm{~g}^{-1}$ ) in the $\mathrm{NaPF}_{6}$-diglyme electrolyte calculated from the $\mathrm{CV}$ curve was higher than those of $\mathrm{Sb}_{2} \mathrm{~S}_{3} / \mathrm{C}\left(726 \mathrm{~F} \mathrm{~g}^{-1}\right.$, $\left.545 \mathrm{~mA} \mathrm{~h} \mathrm{~g}^{-1}\right), \mathrm{SnS}_{2} / \mathrm{C}\left(953 \mathrm{~F} \mathrm{~g}^{-1}, 715 \mathrm{~mA} \mathrm{~h} \mathrm{~g}^{-1}\right)$, and their mixture $\left(676 \mathrm{~F} \mathrm{~g}^{-1}, 507 \mathrm{~mA} \mathrm{~h} \mathrm{~g}^{-1}\right)$. Similarly, Fig. 3b shows that the capacitance of $\mathrm{Sb}_{2} \mathrm{~S}_{3} / \mathrm{SnS}_{2} / \mathrm{C}$ in the $\mathrm{NaPF}_{6}-\mathrm{EC} / \mathrm{DMC}$ electrolyte was $531 \mathrm{~F} \mathrm{~g}^{-1}\left(398 \mathrm{~mA} \mathrm{~h} \mathrm{~g}^{-1}\right)$, which was superior to those of $\mathrm{Sb}_{2} \mathrm{~S}_{3} / \mathrm{C}\left(173 \mathrm{~F} \mathrm{~g}^{-1}, 130 \mathrm{~mA} \mathrm{~h} \mathrm{~g}^{-1}\right), \mathrm{SnS}_{2} / \mathrm{C}\left(174 \mathrm{~F} \mathrm{~g}^{-1}\right.$, $\left.131 \mathrm{~mA} \mathrm{~h} \mathrm{~g}^{-1}\right)$, and their mixture $\left(125 \mathrm{~F} \mathrm{~g}^{-1}, 94 \mathrm{~mA} \mathrm{~h} \mathrm{~g}^{-1}\right)$. Thus, the system of $\mathrm{Sb}_{2} \mathrm{~S}_{3} / \mathrm{SnS}_{2} / \mathrm{C}$ heterojunction composites in the $\mathrm{NaPF}_{6}$-diglyme electrolyte was chosen for the following indepth measurements. According to previous reports, a nanodiamond is characterized by a large specific surface area and chemical inertness; as such, ions can easily adsorb on its surface and form a stable SEI film, thus reducing the occurrence of side reactions [34-37]. Here, the nanodiamond dispersion with a mass content of $5 \%$ was used to modify the separator, which not only helped increase the amount of electrolyte adsorbed but also maintained the integrity of the separator. Fig. S6 shows the results of the CV tests of the half cells using the $\mathrm{Sb}_{2} \mathrm{~S}_{3} / \mathrm{SnS}_{2} / \mathrm{C}$ electrode in the $\mathrm{NaPF}_{6}$-diglyme electrolyte with/without nanodiamond-modified separators. After calculation, the capacitance of the battery with the nanodiamond-modified separator $\left(1453 \mathrm{~F} \mathrm{~g}^{-1}, 1090 \mathrm{~mA} \mathrm{~h} \mathrm{~g}^{-1}\right.$ ) was higher than that without modification (1033 $\mathrm{F} \mathrm{g}^{-1}, 775 \mathrm{~mA} \mathrm{~h} \mathrm{~g}^{-1}$ ). Therefore, the embellishment with nanodiamonds helps improve the electrochemical performance.

A series of comparative tests were carried out to examine the $\mathrm{Na}$-storage performance of the electrode based on $\mathrm{Sb}_{2} \mathrm{~S}_{3} / \mathrm{SnS}_{2} / \mathrm{C}$ composites in different electrolytes. Fig. 4a shows the CV curves of the $\mathrm{Sb}_{2} \mathrm{~S}_{3} / \mathrm{SnS}_{2} / \mathrm{C}$ electrode in two kinds of electrolytes at a sweep rate of $1 \mathrm{mV} \mathrm{s}^{-1}$ with the potential range of $0.01-3.0 \mathrm{~V}$.
The integral area of the $\mathrm{Sb}_{2} \mathrm{~S}_{3} / \mathrm{SnS}_{2} / \mathrm{C}$ electrode in the $\mathrm{NaPF}_{6}$ diglyme electrolyte was larger than that in the $\mathrm{NaPF}_{6}-\mathrm{EC} / \mathrm{DMC}$ electrolyte (Fig. 3). This result implies that using ether-based electrolytes could help enhance electrochemical performance. Fig. S7 illustrates the GCD profiles of the $\mathrm{Sb}_{2} \mathrm{~S}_{3} / \mathrm{SnS}_{2} / \mathrm{C}$ electrode for the first two cycles at $1 \mathrm{~A} \mathrm{~g}^{-1}$ in the two kinds of electrolytes. Based on the profiles, the histogram of the charging and discharging capacities is ploted (Fig. 4b). The initial discharging and charging capacities of the $\mathrm{Sb}_{2} \mathrm{~S}_{3} / \mathrm{SnS}_{2} / \mathrm{C}$ electrode in the $\mathrm{NaPF}_{6}$-diglyme electrolyte were 924.3 and $540.7 \mathrm{~mA} \mathrm{~h} \mathrm{~g}^{-1}$ with a Coulombic efficiency of $58 \%$, respectively. In the second cycle, a Coulombic efficiency of $83.7 \%$ could be recovered. By comparison, the original discharging and charging capacities of the $\mathrm{Sb}_{2} \mathrm{~S}_{3} / \mathrm{SnS}_{2} / \mathrm{C}$ electrode in the $\mathrm{NaPF}_{6}$-EC/DMC electrolyte were lower, i.e., 529.2 and $222.1 \mathrm{~mA} \mathrm{~h} \mathrm{~g}^{-1}$, with a Coulombic efficiency of $41.9 \%$. The Coulombic efficiency of the second cycle was restored to $61.7 \%$. Consequently, the irreversible capacity loss in the $\mathrm{NaPF}_{6}-\mathrm{EC} / \mathrm{DMC}$ electrolyte was higher than that in the diglyme solvent. Fig. $4 \mathrm{c}$ displays the EIS of the devices in different solvents with frequencies of $10^{6}$ to $0.01 \mathrm{~Hz}$. The charge transfer resistance of the $\mathrm{Sb}_{2} \mathrm{~S}_{3} / \mathrm{SnS}_{2} / \mathrm{C}$ electrode in the $\mathrm{NaPF}_{6}$ EC/DMC electrolyte $(632 \Omega)$ was larger than that in the $\mathrm{NaPF}_{6}$ diglyme electrolyte $(101 \Omega)$. According to the report, the reduction voltage of the EC/DMC solvent is higher than that of the diglyme solvent, and the former is more easily reduced on the surface of the electrode than the latter [24]. Hence, electrolyte decomposition can lead to SEI film formation, causing the charge transfer resistance to increase. Fig. S8 presents the corresponding equivalent circuit diagram of the fabricated batteries, where $R_{\mathrm{s}}$ represents the ohmic electrolyte resistance, $R_{\mathrm{p}}$ denotes the charge transfer resistance, CPE expresses constant phase elements, and $W$ depicts the ion-diffusion resistance [38]. Additionally, the GITT measurement within the potential range 

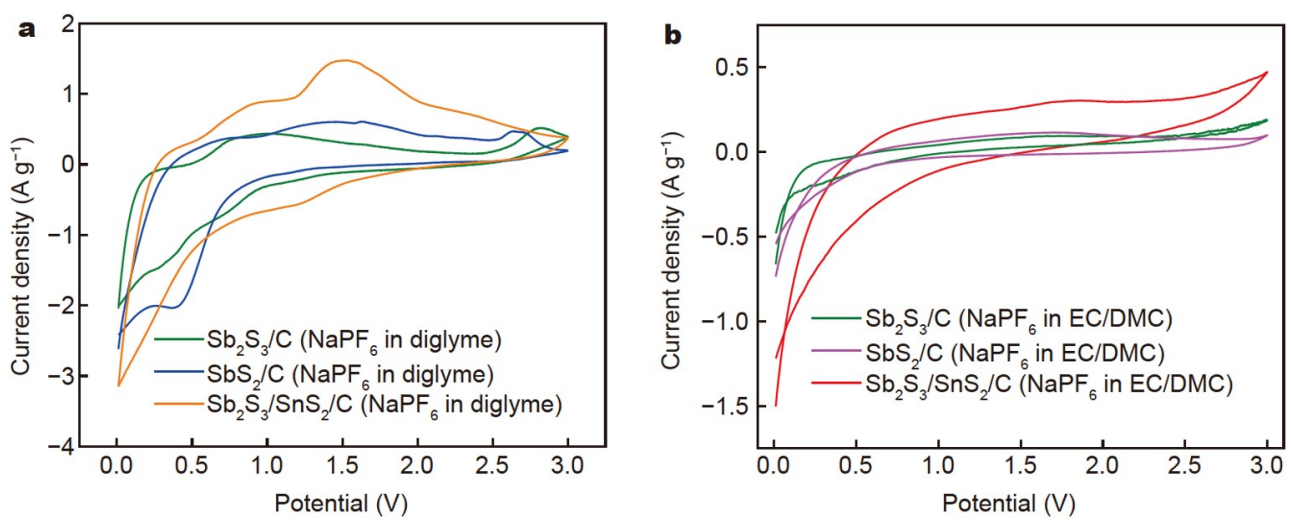

Figure $3 \mathrm{CV}$ curves of sodium-ion half cells based on $\mathrm{Sb}_{2} \mathrm{~S}_{3} / \mathrm{C}, \mathrm{SnS}_{2} / \mathrm{C}$, and $\mathrm{Sb}_{2} \mathrm{~S}_{3} / \mathrm{SnS}_{2} / \mathrm{C}$ electrodes at a scan rate of $1 \mathrm{mV} \mathrm{s}^{-1}$ in $\left(\right.$ a) $\mathrm{NaPF}_{6}$-diglyme electrolyte and (b) $\mathrm{NaPF}_{6}-\mathrm{EC} / \mathrm{DMC}$ electrolyte.
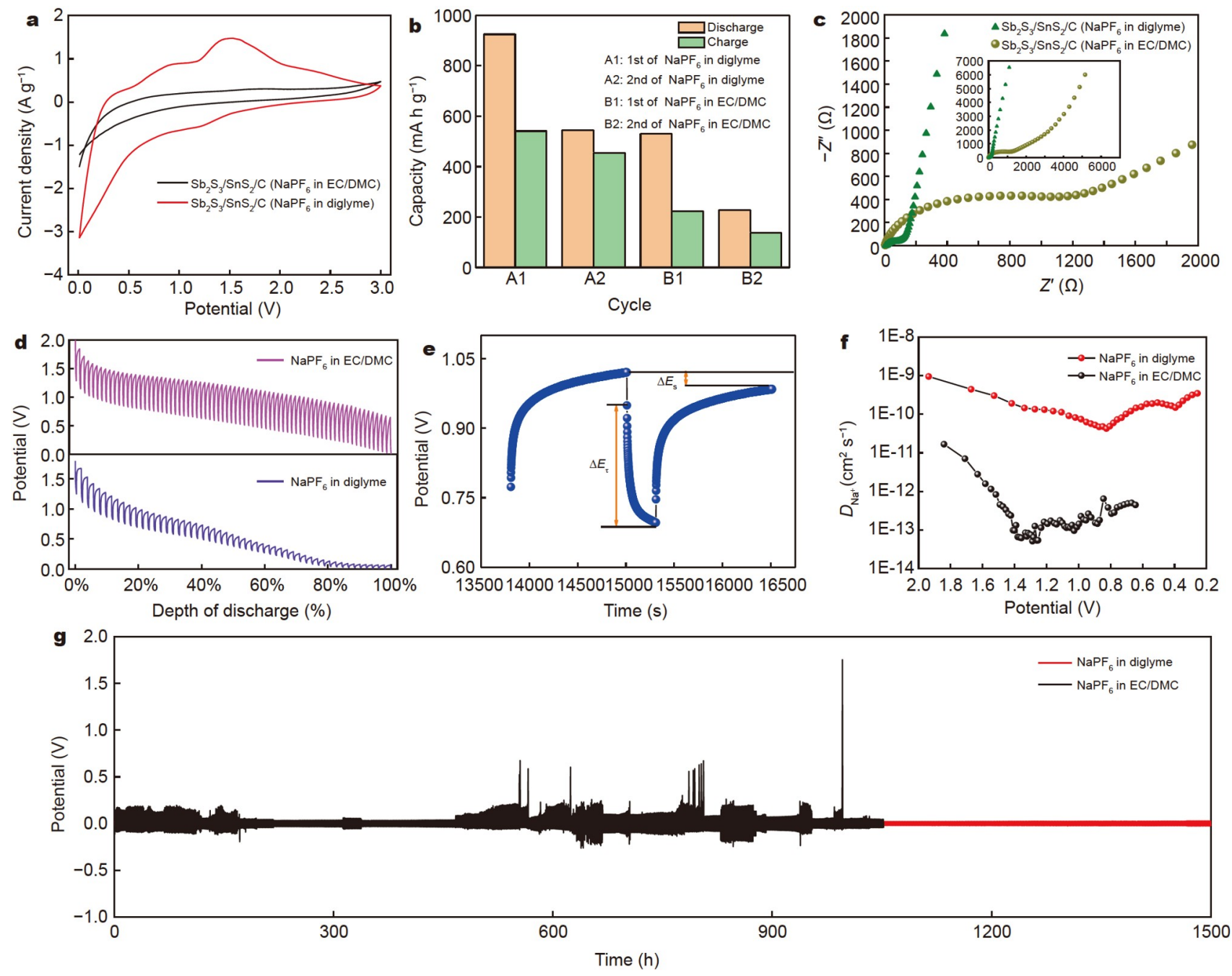

Figure 4 Comparison of the electrochemical properties of the $\mathrm{Sb}_{2} \mathrm{~S}_{3} / \mathrm{SnS}_{2} / \mathrm{C}$ electrode in $\mathrm{NaPF}_{6}$-diglyme and $\mathrm{NaPF}_{6}$-EC/DMC electrolytes. (a) CV curves at a sweep rate of $1 \mathrm{mV} \mathrm{s}^{-1}$. (b) Histogram of the charging/discharging capacities of the first two cycles at a current density of $1 \mathrm{~A} \mathrm{~g}^{-1}$. (c) Magnified Nyquist plots. Inset is the Nyquist impedance plot of the devices in different electrolytes. (d) Discharging curves of the GITT profiles. (e) Detailed change in the potential of the $\mathrm{Sb}_{2} \mathrm{~S}_{3} / \mathrm{SnS}_{2} / \mathrm{C}$ electrode in $\mathrm{NaPF}_{6}$-diglyme electrolyte during a single step of pulse and relaxation. (f) Diffusion coefficients of $\mathrm{Na}^{+}$during the discharging process. (g) Charge-discharge curves of symmetrical Na//Na cells with two different electrolytes at $0.3 \mathrm{~mA} \mathrm{~cm}^{-2}$.

of $0.01-3.0 \mathrm{~V}$ was conducted to investigate the sodium-ion storage kinetics in the two kinds of electrolytes (Fig. 4d). In the single-step GITT test, the cell was discharged at $0.05 \mathrm{~A} \mathrm{~g}^{-1}$ for
5 min and subjected to relaxation for 20 min to achieve a steadystate potential (Fig. 4e and Fig. S9) according to the calculation formula [33]: 
$D_{\mathrm{Na}^{+}}=\frac{4}{\pi \tau}\left(\frac{m_{\mathrm{B}} V_{\mathrm{M}}}{M_{\mathrm{B}} S}\right)^{2}\left(\frac{\Delta E_{\mathrm{S}}}{\Delta E_{\tau}}\right)^{2}$,

where $m_{\mathrm{B}}, V_{\mathrm{M}}$, and $M_{\mathrm{B}}$ are the mass, molar volume, and molar weight of the active materials, respectively; $\tau$ is the pulse time; $S$ is the surface area of electrodes; $\Delta E_{\mathrm{s}}$ and $\Delta E_{\tau}$ are the potential drops between two adjacent steady states and the voltage change after subtracting the $I R$ drop in a single titration. $D_{\mathrm{Na}^{+}}$of the $\mathrm{Sb}_{2} \mathrm{~S}_{3} / \mathrm{SnS}_{2} / \mathrm{C}$ electrode in the $\mathrm{NaPF}_{6}$-diglyme electrolyte was in the range of $4.3 \times 10^{-11}$ to $9.5 \times 10^{-10} \mathrm{~cm}^{2} \mathrm{~s}^{-1}$ (Fig. 4f), which was higher than that in the $\mathrm{NaPF}_{6}-\mathrm{EC} / \mathrm{DMC}$ electrolyte $\left(5.1 \times 10^{-14}\right.$ to $1.6 \times 10^{-11} \mathrm{~cm}^{2} \mathrm{~s}^{-1}$ ), because ether-based electrolytes can effectively accelerate sodium-ion diffusion and electron transport [39]. Furthermore, the long-term cycling stability and compatibility of the two kinds of electrolytes with $\mathrm{Na}$ metal were explored in symmetrical $\mathrm{Na} / / \mathrm{Na}$ cells. Fig. $4 \mathrm{~g}$ shows the charging and discharging curves of the devices at the current density of $0.3 \mathrm{~mA} \mathrm{~cm}{ }^{-2}$. In comparison with $\mathrm{Na} / \mathrm{NaPF}_{6}-(\mathrm{EC} / \mathrm{DMC}) / \mathrm{Na}$, the voltage of the $\mathrm{Na} / \mathrm{NaPF}_{6}-$ Diglyme/Na device appeared relatively stable at $25 \mathrm{mV}$ for $1500 \mathrm{~h}$; as such, it contributed to the increased ionic conductivity and electrochemical stability of the $\mathrm{NaPF}_{6}$-diglyme electrolyte [40]. Therefore, the $\mathrm{NaPF}_{6}$-diglyme electrolyte system can be used to improve the electrochemical performance of the $\mathrm{Sb}_{2} \mathrm{~S}_{3} / \mathrm{SnS}_{2} / \mathrm{C}$ electrode effectively.

The electrochemical properties of $\mathrm{Sb}_{2} \mathrm{~S}_{3} / \mathrm{C}, \mathrm{SnS}_{2} / \mathrm{C}$, and $\mathrm{Sb}_{2} \mathrm{~S}_{3} /$ $\mathrm{SnS}_{2} / \mathrm{C}$ electrode materials in the $\mathrm{NaPF}_{6}$-diglyme electrolyte were tested to further illustrate the advantages of the $\mathrm{Sb}_{2} \mathrm{~S}_{3} / \mathrm{SnS}_{2} / \mathrm{C}$ heterojunction material for Na-ion storage. Fig. $5 \mathrm{a}$ shows the charging and discharging capacities of $\mathrm{Sb}_{2} \mathrm{~S}_{3} / \mathrm{C}, \mathrm{SnS}_{2} / \mathrm{C}$, and $\mathrm{Sb}_{2} \mathrm{~S}_{3} / \mathrm{SnS}_{2} / \mathrm{C}$ electrodes at $1 \mathrm{~A} \mathrm{~g}^{-1}$ for the first two cycles. The maximum discharging and charging capacities of the $\mathrm{Sb}_{2} \mathrm{~S}_{3} / \mathrm{SnS}_{2} /$ $\mathrm{C}$ electrode were 924.3 and $540.7 \mathrm{~mA} \mathrm{~h} \mathrm{~g}^{-1}$ with the first Coulombic efficiency of $58 \%$, respectively. In the second cycle, the Coulombic efficiency could be recovered to $83.7 \%$. By contrast, the original discharging/charging capacities of the $\mathrm{Sb}_{2} \mathrm{~S}_{3} / \mathrm{C}$ and $\mathrm{SnS}_{2} / \mathrm{C}$ electrodes in the same ether-based electrolyte were 943.1/ 360.9 and $806.3 / 218.4 \mathrm{~mA} \mathrm{~h} \mathrm{~g}^{-1}$, respectively, and their initial Coulombic efficiencies were $38.3 \%$ and $27.1 \%$, respectively. In the second cycle, the Coulombic efficiencies returned to $43.1 \%$ and $76.3 \%$, respectively. Thus, the capacity retention of the $\mathrm{Sb}_{2} \mathrm{~S}_{3} / \mathrm{SnS}_{2} / \mathrm{C}$ heterostructure material is much higher than those of $\mathrm{Sb}_{2} \mathrm{~S}_{3} / \mathrm{C}$ and $\mathrm{SnS}_{2} / \mathrm{C}$. Fig. $5 \mathrm{~b}$ shows the Nyquist plots of the $\mathrm{Sb}_{2} \mathrm{~S}_{3} / \mathrm{C}, \mathrm{SnS}_{2} / \mathrm{C}$, and $\mathrm{Sb}_{2} \mathrm{~S}_{3} / \mathrm{SnS}_{2} / \mathrm{C}$ electrodes. The charge transfer resistance of $\mathrm{Sb}_{2} \mathrm{~S}_{3} / \mathrm{SnS}_{2} / \mathrm{C}(101 \Omega)$ was lower than those of the $\mathrm{Sb}_{2} \mathrm{~S}_{3} / \mathrm{C}(196 \Omega)$ and $\mathrm{SnS}_{2} / \mathrm{C}$ electrodes $(185 \Omega)$, because of the heterogeneous structure, which facilitates the charge transfer and ion diffusion [21]. $D_{\mathrm{Na}^{+}}$of $\mathrm{Sb}_{2} \mathrm{~S}_{3} / \mathrm{SnS}_{2} / \mathrm{C}\left(4.3 \times 10^{-11}-9.5 \times\right.$ $\left.10^{-10} \mathrm{~cm}^{2} \mathrm{~s}^{-1}\right)$ was much higher than those of $\mathrm{Sb}_{2} \mathrm{~S}_{3} / \mathrm{C}(1.0 \times$ $\left.10^{-13}-4.7 \times 10^{-10} \mathrm{~cm}^{2} \mathrm{~s}^{-1}\right)$ and $\mathrm{SnS}_{2} / \mathrm{C}\left(4.5 \times 10^{-13}-5.1 \times\right.$ $10^{-10} \mathrm{~cm}^{2} \mathrm{~s}^{-1}$ ) electrodes in the $\mathrm{NaPF}_{6}$-diglyme electrolyte (Fig. 5c). Therefore, heterogeneous structures contribute to the ionic diffusion.

The long-term cycling stability of the $\mathrm{Sb}_{2} \mathrm{~S}_{3} / \mathrm{C}, \mathrm{SnS}_{2} / \mathrm{C}$, and $\mathrm{Sb}_{2} \mathrm{~S}_{3} / \mathrm{SnS}_{2} / \mathrm{C}$ electrodes was examined at the current density of
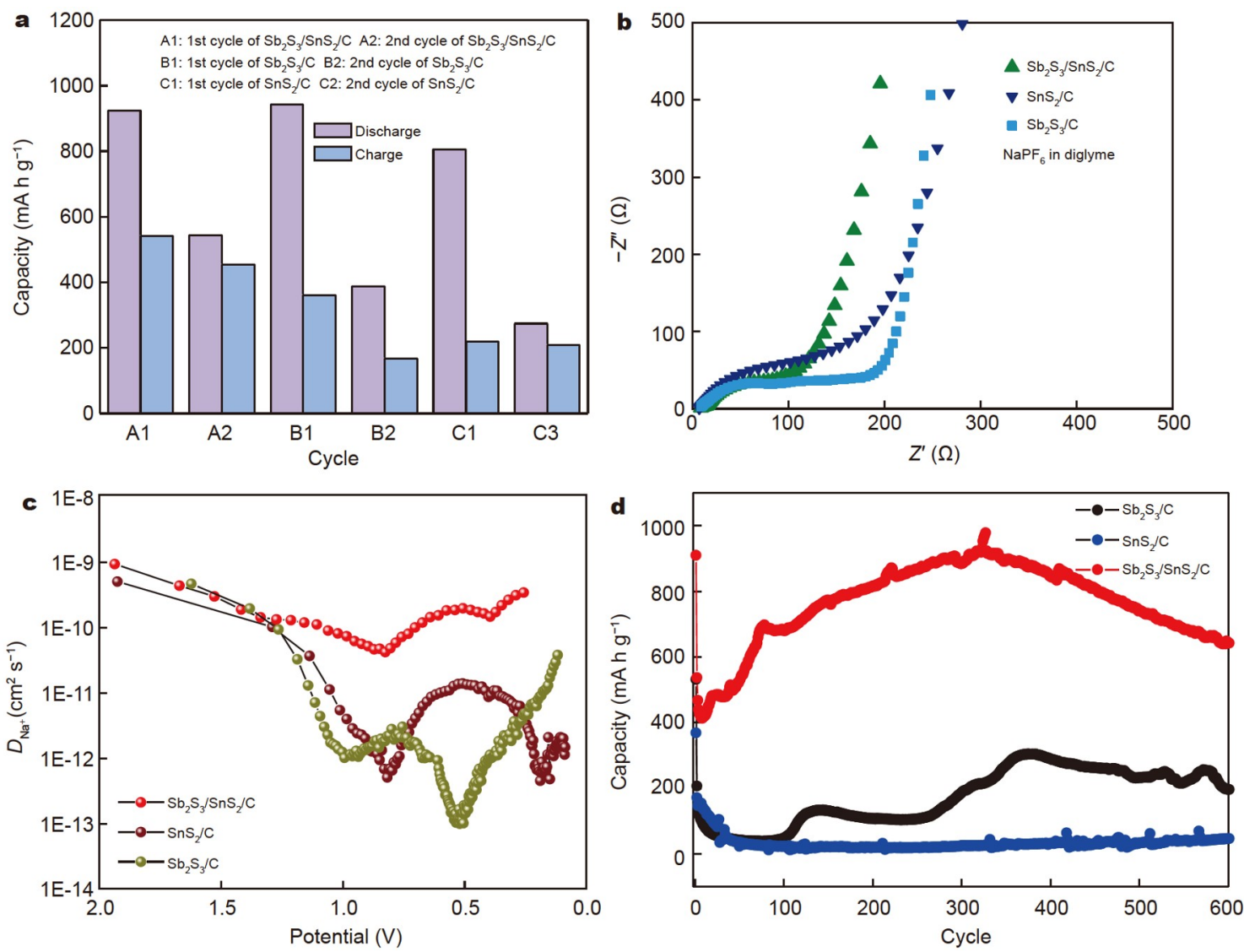

Figure 5 Comparison of the electrochemical performance of $\mathrm{Sb}_{2} \mathrm{~S}_{3} / \mathrm{C}, \mathrm{SnS}_{2} / \mathrm{C}$, and $\mathrm{Sb}_{2} \mathrm{~S}_{3} / \mathrm{SnS}_{2} / \mathrm{C}$ electrodes in the $\mathrm{NaPF}_{6}$-diglyme electrolyte. (a) $\mathrm{Charge}$ and discharge capacities in the first two cycles at a current density of $1 \mathrm{~A} \mathrm{~g}^{-1}$. (b) Nyquist plots. (c) Diffusion coefficients of $\mathrm{Na}^{+}$during the discharging process. (d) Cycling stability at a current density of $1 \mathrm{~A} \mathrm{~g}^{-1}$. 
$1 \mathrm{~A} \mathrm{~g}^{-1}$ (Fig. 5d). The capacity of the $\mathrm{Sb}_{2} \mathrm{~S}_{3} / \mathrm{SnS}_{2} / \mathrm{C}$ electrode decreased in the first 10 cycles. In the next 300 cycles, the capacity increased until it reached $920 \mathrm{~mA} \mathrm{~h} \mathrm{~g}^{-1}$. In the following cycles, the electrochemical performance gradually decreased, and the final reversible capacity was $642 \mathrm{~mA} \mathrm{~h} \mathrm{~g}^{-1}$ at the 600 th cycle. Therefore, the electrochemical performance and lifespan improved compared with those of previous results $[17,20]$. This remarkable fluctuation could be attributed to the insufficient active surface area in a pristine state. As the reaction proceeded, more electrolytes on the surface penetrated the materials, and more active materials participated in electrochemical reactions; consequently, capacity rapidly increased. In addition, sulfides tended to expand during electrochemical reactions. The decreased capacity is possibly caused by the structural pulverization and incomplete conversion during the cycling process $[41,42]$. A roughly similar trend was observed in the $\mathrm{Sb}_{2} \mathrm{~S}_{3} / \mathrm{C}$ electrode, whose capacity gradually decreased in the first 100 cycles, increased in the next 250 cycles, and finally decreased to $196 \mathrm{~mA} \mathrm{~h} \mathrm{~g}^{-1}$. For the $\mathrm{SnS}_{2} / \mathrm{C}$ electrode, the capacity was severely reduced to $100 \mathrm{~mA} \mathrm{~h} \mathrm{~g}^{-1}$ after 20 cycles. Therefore, the electrochemical performance of the $\mathrm{Sb}_{2} \mathrm{~S}_{3} / \mathrm{SnS}_{2} / \mathrm{C}$ electrode material is relatively better than that of the other electrodes. Transition metal composites usually experience an increase in capacity during cycles because of the activation of electrode materials and the reversible formation of organic polymers through electrolyte degradation [25,43-46].

The sodium-ion storage behavior of the $\mathrm{Sb}_{2} \mathrm{~S}_{3} / \mathrm{SnS}_{2} / \mathrm{C}$ materials in the $\mathrm{NaPF}_{6}$-diglyme electrolyte was further investigated. Fig. 6a shows the CV curves of the half cell for the first three cycles at a scan rate of $1 \mathrm{mV} \mathrm{s}^{-1}$. During the first cathodic process, the sharp peaks at about 1.72 and $1.45 \mathrm{~V}$ correspond to $\mathrm{Na}^{+}$intercalation in $\mathrm{SnS}_{2}$ layers to form $\mathrm{NaSnS}_{2}[16,20,33,47,48]$ : $\mathrm{SnS}_{2}+\mathrm{Na}^{+}+\mathrm{e}^{-} \rightarrow \mathrm{NaSnS}_{2}$.

The broad reduction peak ranging from 1.3 to $0.86 \mathrm{~V}$ is attributed to the overlapping conversion reactions of $\mathrm{Sb}_{2} \mathrm{~S}_{3}$ and $\mathrm{SnS}_{2}[17-20,22,23,33,49]$ :

$\mathrm{Sb}_{2} \mathrm{~S}_{3}+6 \mathrm{Na}^{+}+6 \mathrm{e}^{-} \rightarrow 2 \mathrm{Sb}+3 \mathrm{Na}_{2} \mathrm{~S}$,

$\mathrm{NaSnS}_{2}+3 \mathrm{Na}^{+}+3 \mathrm{e}^{-} \rightarrow \mathrm{Sn}+2 \mathrm{Na}_{2} \mathrm{~S}$.

Another long slope from 0.65 and $0.3 \mathrm{~V}$ is ascribed to the alloying reactions of $\mathrm{Sb}$ and $\mathrm{Sn}[16-18,20,48-50]$. Besides, an irreversible SEI layer is formed in this region $[17,18]$ :

$2 \mathrm{Sb}+6 \mathrm{Na}^{+}+6 \mathrm{e}^{-} \rightarrow 2 \mathrm{Na}_{3} \mathrm{Sb}$,

$\mathrm{Sn}+3.75 \mathrm{Na}^{+}+3.75 \mathrm{e}^{-} \rightarrow \mathrm{Na}_{3.75} \mathrm{Sn}$.

In the anodic scan, the oxidation peaks at 0.3 and $0.76 \mathrm{~V}$ are related to the desodiation of $\mathrm{Na}_{3.75} \mathrm{Sn}$ and $\mathrm{Na}_{3} \mathrm{Sb}$, respectively $[17,18,20,23,48,49]$. The broad anodic peak centered at $1.4 \mathrm{~V}$ is attributed to the reformation of $\mathrm{Sb}_{2} \mathrm{~S}_{3}$ and $\mathrm{NaSnS}_{2}$. An indistinct peak concentrated at $2.2 \mathrm{~V}$ is assigned to the sodium-ion extracted from $\mathrm{NaSnS}_{2}$ [48]. In the subsequent cycles, the location of the peaks slightly changed, possibly because of the SEI film formation with irreversible side reactions [18]. Fig. 6b displays the GCD curves of the 1st, 2nd, 3rd, 100th, 200th, and 300 th cycles at $1 \mathrm{~A} \mathrm{~g}^{-1}$. In the first few anodic cycles, the activation barrier for desodiation was high. As the materials expanded in volume and the particles size became smaller in the subsequent cycles, the kinetic barrier decreased, indicating that the reaction kinetics accelerated. Therefore, the initial anodic reaction platform decreased below $2.0 \mathrm{~V}$ in the 100th, 200th, and 300th cycles [51,52].

The first discharging and charging capacities of the $\mathrm{Sb}_{2} \mathrm{~S}_{3} /$ $\mathrm{SnS}_{2} / \mathrm{C}$ electrode were 924.3 and $540.7 \mathrm{~mA} \mathrm{~h} \mathrm{~g}^{-1}$, respectively. Simultaneously, the discharging capacities of the 100th, 200th, and 300th cycles $\left(680,814.3\right.$, and $882.1 \mathrm{~mA} \mathrm{~h} \mathrm{~g}^{-1}$, respectively) were much higher than those of the 2nd and 3rd cycles (535 and $465.7 \mathrm{~mA} \mathrm{~h} \mathrm{~g}^{-1}$, respectively), which were consistent with the results shown in Fig. 5d. Fig. 6c illustrates the rate property of $\mathrm{Sb}_{2} \mathrm{~S}_{3} / \mathrm{SnS}_{2} / \mathrm{C}$ in the $\mathrm{NaPF}_{6}$-diglyme electrolyte with current densities of $0.1-4.0 \mathrm{~A} \mathrm{~g} \mathrm{~g}^{-1}$. The average capacities of 929.8, 684.9,
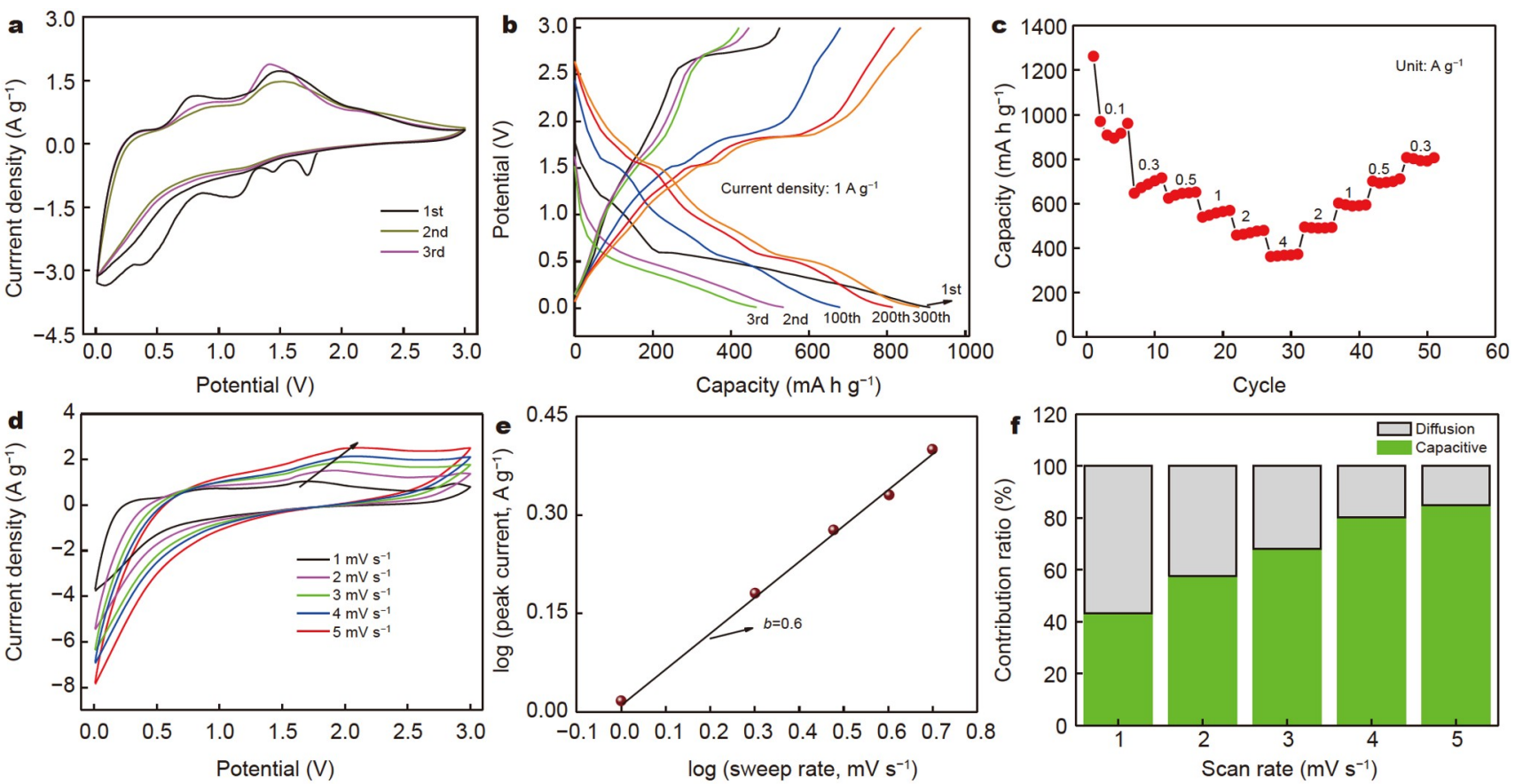

Figure 6 Sodium-ion storage performance of the $\mathrm{Sb}_{2} \mathrm{~S}_{3} / \mathrm{SnS}_{2} / \mathrm{C}$ electrode in the $\mathrm{NaPF}_{6}$-diglyme electrolyte. (a) CV curves of the first three cycles at a sweep rate of $1 \mathrm{mV} \mathrm{s}^{-1}$. (b) GCD profiles at the current density of $1 \mathrm{~A} \mathrm{~g}^{-1}$. (c) Rate capability. (d-f) CV curves, peak current, and diffusion and capacitive contributions at different scan rates of $1-5 \mathrm{mV} \mathrm{s}^{-1}$. 
641.9, 555.8, 469.1, and $367.3 \mathrm{~mA} \mathrm{~h} \mathrm{~g}^{-1}$ at $0.1,0.3,0.5,1.0,2.0$, and $4.0 \mathrm{~A} \mathrm{~g}^{-1}$ were achieved, respectively. When the current density was returned to $0.3 \mathrm{~A} \mathrm{~g}^{-1}$, an improved specific capacity of $800.2 \mathrm{~mA} \mathrm{~h} \mathrm{~g}^{-1}$ could be obtained because of the activation process, demonstrating the decent rate performance of the $\mathrm{Sb}_{2} \mathrm{~S}_{3} /$ $\mathrm{SnS}_{2} / \mathrm{C}$ materials. In addition, the $\mathrm{CV}$ curves at various scan rates of $1-5 \mathrm{mV} \mathrm{s}^{-1}$ were obtained to reveal the possible reason for superior rate properties (Fig. 6d). Because $\mathrm{Sb}_{2} \mathrm{~S}_{3}$ and $\mathrm{SnS}_{2}$ are pseudocapacitance materials, the electrochemical capacity generally included the diffusion-controlled value and the surface capacitive contribution according to the following computational formula:

$i=a v^{b}$,

where $a$ and $b$ are two adjustable parameters, $i$ is the current $\left(\mathrm{A} \mathrm{g}^{-1}\right)$, and $v$ is the scan rate $\left(\mathrm{mV} \mathrm{s}^{-1}\right)$ [53]. Specifically, the $b$ values of 0.5 and 1 illustrate that the charge storage is dominated by the diffusion-controlled process and surface capacitive contribution, respectively. In Fig. 6e, the $b$-value of the anodic peak was 0.6 , suggesting that the capacitive contribution and diffusion-controlled process coexisted. Moreover, the surface capacitive contribution can be inferred by the following formula [54]: $i=k_{1} v+k_{2} v^{1 / 2}$,

where $k_{1} v$ and $k_{2} v^{1 / 2}$ are the values of the surface capacitive and diffusion-controlled contributions at the given specific voltage, respectively. Thus, the capacitive contribution profile of the $\mathrm{Sb}_{2} \mathrm{~S}_{3} / \mathrm{SnS}_{2} / \mathrm{C}$ electrode was $43.2 \%$ at the scan rate of $1 \mathrm{mV} \mathrm{s}^{-1}$ (Fig. S10). Encouragingly, the surface capacitive contribution improved as the scan rate increased (Fig. 61), which could reach $84.8 \%$ at $5 \mathrm{mV} \mathrm{s}^{-1}$. The high proportion of capacitive contribution could help enhance the rate performance of electrode materials. In addition, a $\mathrm{Na}$-ion full cell was assembled by pairing with a $\mathrm{Na}_{3} \mathrm{~V}\left(\mathrm{PO}_{3}\right)_{3} \mathrm{~N}$ cathode [55]. Fig. S11 shows the electrochemical performance of the full cell. A typical discharge curve of the Na-ion full cell displays a specific capacity of $348 \mathrm{~mA} \mathrm{~h} \mathrm{~g}^{-1}$ at $0.1 \mathrm{~A} \mathrm{~g}^{-1}$ under the potential of $1-4 \mathrm{~V}$ (based on the weight of the anode). Moreover, a good capacity retention of $81 \%$ was retained after 40 cycles at $0.1 \mathrm{~A} \mathrm{~g}^{-1}$. Simultaneously, the energy and power densities of the full cell were calculated using the formulas described in previous reports [56]. The maximum energy density was $120 \mathrm{~W} \mathrm{~h} \mathrm{~kg}^{-1}$ based on the total mass of anode and cathode materials.

\section{CONCLUSION}

In summary, a one-dimensional $\mathrm{Sb}_{2} \mathrm{~S}_{3} / \mathrm{SnS}_{2} / \mathrm{C}$ heterostructure was successfully prepared by directly growing $\mathrm{SnS}_{2}$ nanoplates on $\mathrm{Sb}_{2} \mathrm{~S}_{3}$ nanorods and then coating their surface with a carbon layer. The electrochemical performance of the obtained heterostructure is superior to that of individual $\mathrm{Sb}_{2} \mathrm{~S}_{3} / \mathrm{C}$ and $\mathrm{SnS}_{2} / \mathrm{C}$ electrodes. The sodium-ion storage property improves because (i) the $\mathrm{Sb}_{2} \mathrm{~S}_{3} / \mathrm{SnS}_{2} / \mathrm{C}$ composites with a special heterogeneous structure could induce an electric field within the nanocrystals, consequently decreasing their ion-diffusion resistance and promoting ion and electron transport. (ii) The carbon coating not only enhances electrical conductivity but also alleviates volume expansion in the sodiation/desodiation process. (iii) The etherbased electrolyte with lower reduction voltage can facilitate the formation of a thinner and more stable SEI film on the electrode surface than that in a carbonate-based electrolyte. Consequently, the charge transfer resistance decreases. Thus, the following electrochemical properties of the $\mathrm{Sb}_{2} \mathrm{~S}_{3} / \mathrm{SnS}_{2} / \mathrm{C}$ electrode are obtained: a reversible capacity of $642 \mathrm{~mA} \mathrm{~h} \mathrm{~g}^{-1}$ at $1 \mathrm{~A} \mathrm{~g}^{-1}$ after
600 times cycles and a good rate performance of $367.3 \mathrm{~mA} \mathrm{~h} \mathrm{~g}^{-1}$ at an increased current density of $4 \mathrm{~A} \mathrm{~g}^{-1}$. Indeed, $\mathrm{Sb}_{2} \mathrm{~S}_{3} / \mathrm{SnS}_{2} / \mathrm{C}$ heterostructures are competitive anode materials for SIBs.

\section{Received 13 October 2021; accepted 14 December 2021; published online 14 February 2022}

1 Wang Y, Yang Q, Zhao Y, et al. Recent advances in electrode fabrication for flexible energy-storage devices. Adv Mater Technol, 2019, 4: 1900083

2 Wang G, He P, Fan LZ. Asymmetric polymer electrolyte constructed by metal-organic framework for solid-state, dendrite-free lithium metal battery. Adv Funct Mater, 2021, 31: 2007198

3 Lee J, Wang C, Malik R, et al. Determining the criticality of Li-excess for disordered-rocksalt Li-ion battery cathodes. Adv Energy Mater, 2021, 11: 2100204

4 Lin J, Zeng C, Lin X, et al. Metal-organic framework-derived hierarchical $\mathrm{MnO} / \mathrm{Co}$ with oxygen vacancies toward elevated-temperature Li-ion battery. ACS Nano, 2021, 15: 4594-4607

5 Zuo W, Li R, Zhou C, et al. Battery-supercapacitor hybrid devices: Recent progress and future prospects. Adv Sci, 2017, 4: 1600539

6 Wang H, Zhu C, Chao D, et al. Nonaqueous hybrid lithium-ion and sodium-ion capacitors. Adv Mater, 2017, 29: 1702093

7 Choi C, Ashby DS, Butts DM, et al. Achieving high energy density and high power density with pseudocapacitive materials. Nat Rev Mater, 2020, 5: 5-19

8 Zhang L, Wei Q, Sun D, et al. Conversion reaction of vanadium sulfide electrode in the lithium-ion cell: Reversible or not reversible? Nano Energy, 2018, 51: 391-399

9 Wei Q, Jiang Y, Qian X, et al. Sodium ion capacitor using pseudocapacitive layered ferric vanadate nanosheets cathode. iScience, 2018, 6: $212-221$

10 Xia X, Chao D, Zhang Y, et al. Generic synthesis of carbon nanotube branches on metal oxide arrays exhibiting stable high-rate and longcycle sodium-ion storage. Small, 2016, 12: 3048-3058

11 Kim MS, Lim E, Kim S, et al. General synthesis of N-doped macroporous graphene-encapsulated mesoporous metal oxides and their application as new anode materials for sodium-ion hybrid supercapacitors. Adv Funct Mater, 2017, 27: 1603921

12 Kumaresan TK, Masilamani SA, Raman K, et al. High performance sodium-ion battery anode using biomass derived hard carbon with engineered defective sites. Electrochim Acta, 2021, 368: 137574

13 Liu M, Zhang J, Guo S, et al. Chemically presodiated hard carbon anodes with enhanced initial Coulombic efficiencies for high-energy sodium ion batteries. ACS Appl Mater Interfaces, 2020, 12: 1762017627

14 Lao M, Zhang Y, Luo W, et al. Alloy-based anode materials toward advanced sodium-ion batteries. Adv Mater, 2017, 29: 1700622

15 Xiao Y, Lee SH, Sun YK. The application of metal sulfides in sodium ion batteries. Adv Energy Mater, 2016, 7: 1601329

16 Xie X, Su D, Chen S, et al. $\mathrm{SnS}_{2}$ nanoplatelet@graphene nanocomposites as high-capacity anode materials for sodium-ion batteries. Chem Asian J, 2014, 9: 1611-1617

17 Zhu Y, Nie P, Shen L, et al. High rate capability and superior cycle stability of a flower-like $\mathrm{Sb}_{2} \mathrm{~S}_{3}$ anode for high-capacity sodium ion batteries. Nanoscale, 2015, 7: 3309-3315

18 Hou $\mathrm{H}$, Jing $\mathrm{M}$, Huang $\mathrm{Z}$, et al. One-dimensional rod-like $\mathrm{Sb}_{2} \mathrm{~S}_{3}$-based anode for high-performance sodium-ion batteries. ACS Appl Mater Interfaces, 2015, 7: 19362-19369

19 Ren Y, Wang J, Huang X, et al. Three-dimensional $\mathrm{SnS}_{2}$ flowers/carbon nanotubes network: Extraordinary rate capacity for sodium-ion battery. Mater Lett, 2017, 186: 57-61

20 Wang J, Luo C, Mao J, et al. Solid-state fabrication of $\mathrm{SnS}_{2} / \mathrm{C}$ nanospheres for high-performance sodium ion battery anode. ACS Appl Mater Interfaces, 2015, 7: 11476-11481

21 Cao L, Gao X, Zhang B, et al. Bimetallic sulfide $\mathrm{Sb}_{2} \mathrm{~S}_{3} @ \mathrm{FeS}_{2}$ hollow nanorods as high-performance anode materials for sodium-ion batteries. ACS Nano, 2020, 14: 3610-3620

22 Zhang Z, Zhao J, Xu M, et al. Facile synthesis of $\mathrm{Sb}_{2} \mathrm{~S}_{3} / \mathrm{MoS}_{2}$ hetero- 
structure as anode material for sodium-ion batteries. Nanotechnology, 2018, 29: 335401

23 Dong S, Li C, Ge X, et al. ZnS-Sb $\mathrm{S}_{3} @ \mathrm{C}$ core-double shell polyhedron structure derived from metal-organic framework as anodes for high performance sodium ion batteries. ACS Nano, 2017, 11: 6474-6482

24 Zhang J, Wang DW, Lv W, et al. Achieving superb sodium storage performance on carbon anodes through an ether-derived solid electrolyte interphase. Energy Environ Sci, 2017, 10: 370-376

$25 \mathrm{Wu}$ J, Liu J, Cui J, et al. Dual-phase $\mathrm{MoS}_{2}$ as a high-performance sodium-ion battery anode. J Mater Chem A, 2020, 8: 2114-2122

26 Wan Y, Song K, Chen W, et al. Ultra-high initial Coulombic efficiency induced by interface engineering enables rapid, stable sodium storage. Angew Chem Int Ed, 2021, 60: 11481-11486

27 Zhang $\mathrm{M}, \mathrm{Li} \mathrm{Y}, \mathrm{Wu} \mathrm{F}$, et al. Boosting the ultrahigh initial coulombic efficiency of porous carbon anodes for sodium-ion batteries via in situ fabrication of a passivation interface. J Mater Chem A, 2021, 9: 1078010788

28 Sahoo RK, Singh S, Yun JM, et al. $\mathrm{Sb}_{2} \mathrm{~S}_{3}$ nanoparticles anchored or encapsulated by the sulfur-doped carbon sheet for high-performance supercapacitors. ACS Appl Mater Interfaces, 2019, 11: 33966-33977

29 Wang M, Fan L, Wu X, et al. $\mathrm{SnS}_{2} / \mathrm{SnO}_{2}$ heterostructures towards enhanced electrochemical performance of lithium-sulfur batteries. Chem Eur J, 2019, 25: 5416-5421

30 Ge P, Zhang L, Zhao W, et al. Interfacial bonding of metal-sulfides with double carbon for improving reversibility of advanced alkali-ion batteries. Adv Funct Mater, 2020, 30: 1910599

31 Sun XM, Chen X, Deng ZX, et al. A CTAB-assisted hydrothermal orientation growth of $\mathrm{ZnO}$ nanorods. Mater Chem Phys, 2002, 78: 99_ 104

32 Liang $\mathrm{H}, \mathrm{Ni}$ J, Li L. Bio-inspired engineering of $\mathrm{Bi}_{2} \mathrm{~S}_{3}-\mathrm{PPy}$ yolk-shell composite for highly durable lithium and sodium storage. Nano Energy, 2017, 33: 213-220

33 Wang S, Liu S, Li X, et al. $\mathrm{SnS}_{2} / \mathrm{Sb}_{2} \mathrm{~S}_{3}$ heterostructures anchored on reduced graphene oxide nanosheets with superior rate capability for sodium-ion batteries. Chem Eur J, 2018, 24: 3873-3881

34 Cheng XB, Zhao MQ, Chen C, et al. Nanodiamonds suppress the growth of lithium dendrites. Nat Commun, 2017, 8: 336

35 Polino G, Scaramella A, Manca V, et al. Nanodiamond-based separators for supercapacitors realized on paper substrates. Energy Technol, 2020, 8: 1901233

36 Song Y, Li H, Wang L, et al. Nanodiamonds: A critical component of anodes for high performance lithium-ion batteries. Chem Commun, 2016, 52: 10497-10500

37 Postnov VN, Mel'nikova NA, Shul'meister GA, et al. Nafion- and aquivion-based nanocomposites containing detonation nanodiamonds. Russ J Gen Chem, 2017, 87: 2754-2755

38 Jia $\mathrm{R}, \mathrm{Du} \mathrm{H}$, Zhang $\mathrm{X}$, et al. Stretchable and compressible supercapacitor with polyaniline on hydrogel electrolyte. J Electrochem Soc, 2018, 165: A3792-A3798

39 Su D, Kretschmer K, Wang G. Improved electrochemical performance of Na-ion batteries in ether-based electrolytes: A case study of $\mathrm{ZnS}$ nanospheres. Adv Energy Mater, 2016, 6: 1501785

40 Li D, Chen L, Wang T, et al. 3D fiber-network-reinforced bicontinuous composite solid electrolyte for dendrite-free lithium metal batteries. ACS Appl Mater Interfaces, 2018, 10: 7069-7078

$41 \mathrm{Wu}$, Wu ZG, Zhang X, et al. Insight into the origin of capacity fluctuation of $\mathrm{Na}_{2} \mathrm{Ti}_{6} \mathrm{O}_{13}$ anode in sodium ion batteries. ACS Appl Mater Interfaces, 2017, 9: 43596-43602

42 Park JY, Kim SJ, Yim K, et al. Pulverization-tolerance and capacity recovery of copper sulfide for high-performance sodium storage. Adv Sci, 2019, 6: 1900264

43 Jiao Y, Mukhopadhyay A, Ma Y, et al. Ion transport nanotube assembled with vertically aligned metallic $\mathrm{MoS}_{2}$ for high rate lithium-ion batteries. Adv Energy Mater, 2018, 8: 1702779

44 Xue H, Yu DYW, Qing J, et al. Pyrite $\mathrm{FeS}_{2}$ microspheres wrapped by reduced graphene oxide as high-performance lithium-ion battery anodes. J Mater Chem A, 2015, 3: 7945-7949

45 Pan L, Zhu XD, Xie XM, et al. Smart hybridization of $\mathrm{TiO}_{2}$ nanorods and $\mathrm{Fe}_{3} \mathrm{O}_{4}$ nanoparticles with pristine graphene nanosheets: Hier- archically nanoengineered ternary heterostructures for high-rate lithium storage. Adv Funct Mater, 2015, 25: 3341-3350

46 Han W, Qin X, Wu J, et al. Electrosprayed porous $\mathrm{Fe}_{3} \mathrm{O}_{4} /$ carbon microspheres as anode materials for high-performance lithium-ion batteries. Nano Res, 2018, 11: 892-904

47 Zhang $\mathrm{Y}$, Zhu $\mathrm{P}$, Huang $\mathrm{L}$, et al. Few-layered $\mathrm{SnS}_{2}$ on few-layered reduced graphene oxide as $\mathrm{Na}$-ion battery anode with ultralong cycle life and superior rate capability. Adv Funct Mater, 2015, 25: 481-489

48 Fan L, Li X, Song X, et al. Promising dual-doped graphene aerogel/SnS nanocrystal building high performance sodium ion batteries. ACS Appl Mater Interfaces, 2018, 10: 2637-2648

49 Yu DYW, Prikhodchenko PV, Mason CW, et al. High-capacity antimony sulphide nanoparticle-decorated graphene composite as anode for sodium-ion batteries. Nat Commun, 2013, 4: 2922

50 Thangavel R, Pandian AS, Ramasamy HV, et al. Rapidly synthesized, few-layered pseudocapacitive $\mathrm{SnS}_{2}$ anode for high-power sodium ion batteries. ACS Appl Mater Interfaces, 2017, 9: 40187-40196

51 Lee M, Hong J, Lopez J, et al. High-performance sodium-organic battery by realizing four-sodium storage in disodium rhodizonate. Nat Energy, 2017, 2: 861-868

52 Liu Q, Deng W, Sun CF. A potassium-tellurium battery. Energy Storage Mater, 2020, 28: 10-16

53 Wang J, Polleux J, Lim J, et al. Pseudocapacitive contributions to electrochemical energy storage in $\mathrm{TiO}_{2}$ (anatase) nanoparticles. J Phys Chem C, 2007, 111: 14925-14931

54 Cai P, Zou K, Zou G, et al. Quinone/ester-based oxygen functional group-incorporated full carbon Li-ion capacitor for enhanced performance. Nanoscale, 2020, 12: 3677-3685

55 Chen M, Hua W, Xiao J, et al. Development and investigation of a NASICON-type high-voltage cathode material for high-power sodiumion batteries. Angew Chem, 2020, 132: 2470-2477

56 Dong X, Chen L, Su X, et al. Flexible aqueous lithium-ion battery with high safety and large volumetric energy density. Angew Chem Int Ed, 2016, 55: 7474-7477

Acknowledgements This work was supported by the National Natural Science Foundation of China (51972025).

Author contributions The paper was written through the contributions of all authors. All authors have given approval to the final version of the paper.

Conflict of interest The authors declare that they have no conflict of interest.

Supplementary information Supporting data are available in the online version of this paper.

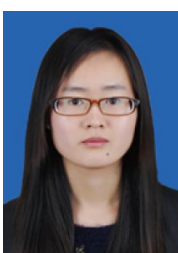

Rui Jia received her BE degree in 2015 from Huaqiao University and ME degree in 2018 from Qingdao University. She is a $\mathrm{PhD}$ candidate at the college of Mathematics and Physics, University of Science and Technology Beijing. Her research interests mainly focus on SIBs and hybrid supercapacitors.

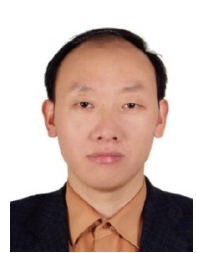

Guozhen Shen received his BSc degree (1999) in chemistry from Anhui Normal University and $\mathrm{PhD}$ degree (2003) in chemistry from the University of Science and Technology of China. He joined the Institute of Semiconductors, Chinese Academy of Sciences as a professor in 2013. His current research focuses on flexible electronics and printable electronics, including transistors, photodetectors, sensors, and flexible energy storage and conversion devices. 
Di Chen received her BSc degree (1999) in chemistry from Anhui Normal University and $\mathrm{PhD}$ degree (2005) in chemistry from the University of Science and Technology of China. She joined the University of Science and Technology Beijing as a professor in 2014. Her current research focuses on energy storage materials and devices.

\section{$\mathrm{Sb}_{2} \mathrm{~S}_{3} / \mathrm{SnS}_{2} / \mathrm{C}$ 异质结材料用于高性能钠离子电池}

贾苅 ${ }^{1,2}$, 李腊 ${ }^{2}$, 沈国震 $2^{*}$, 陈娣 $1^{*}$

摘要 金属硫化物有着较高的理论容量, 是钠离子电池极具潜力的负 极材料. 然而, 这类材料在电化学反应过程中存在体积膨胀和反应动力 学缓慢的缺点, 使得其循环和倍率性能较差. 本文通过在 $\mathrm{Sb}_{2} \mathrm{~S}_{3}$ 纳米棒上 直接生长 $\mathrm{SnS}_{2}$ 纳米片并在其表面进一步包裹碳膜, 制备了 $\mathrm{Sb}_{2} \mathrm{~S}_{3} / \mathrm{SnS}_{2} / \mathrm{C}$ 异质结构. 这种异质结构极大地提高了材料的稳定性, 并促进了离子和 电子的运输. 研究结果表明, 在六氟磷酸钠/二乙二醇二甲醚电解质体 系中充放电循环 600 次后, $\mathrm{Sb}_{2} \mathrm{~S}_{3} / \mathrm{SnS}_{2} / \mathrm{C}$ 复合电极材料在电流密度为 $1 \mathrm{~A} \mathrm{~g}^{-1}$ 时表现出 $642 \mathrm{~mA} \mathrm{~h} \mathrm{~g}^{-1}$ 的高可逆容量, 并且在 $4 \mathrm{~A} \mathrm{~g}^{-1}$ 时仍保留 $367.3 \mathrm{~mA} \mathrm{~h} \mathrm{~g}^{-1}$ 的良好的倍率性能. 此外, 为了研究该材料的电化学性 能, 本工作进一步探讨了钠离子在几种不同的电极材料和电解质中的 扩散过程. 综上所述, $\mathrm{Sb}_{2} \mathrm{~S}_{3} / \mathrm{SnS}_{2} / \mathrm{C}$ 异质结材料有望成为一种拥有广阔 应用前景的钠离子电池负极材料. 